\title{
Influence of Production Receptions on Productivity Perspective Variety of Winter Solid Wheat in Dagestan
}

\author{
NR Magomedov*, NN Magomedov, JN Abdullayev and D Yu Suleymanov \\ FEDERAL state budgetary institution, Federal Agricultural Research Center RD, Russia
}

*Corresponding author: NR Magomedov, Doctor of Agricultural Sciences. Sciences,

Received Date: November 21, 2018

Head Department of Agrarian Landscaping, Russia.

\begin{abstract}
On the meadow-chestnut soil of heavy mechanical composition we studied the productivity of promising varieties of winter durum wheat Grain, de-pending on the doses and timing of mineral fertilizers on the background of irrigation and semi-steam systems of soil treatment in irrigation of the flat zone of Dagestan. The purpose of the research was to obtain experimental data for the development of cost-effective and environmentally friendly resource-saving technology of cultivation of promising varieties of winter durum wheat Grain in the flat zone of Dagestan. The novelty of the research is that for the first time in the conditions of irrigation of the flat zone of Dagestan, the optimal doses of mineral fertilizers and the terms of their application for winter durum wheat, providing a significant in-crease in yield and grain quality were studied and established. On average, for 2014-2018 the maximum yield of the promising Grain variety-5.45 t/ha, on aver-age for 2014-2018, was achieved in the variant of applying an increased dose of mineral fertilizers $\left(\mathrm{N}_{180} \mathrm{P}_{100}\right)$. Application of half dose of mineral fertilizers $\left(\mathrm{N}_{90} \mathrm{P}_{50}\right)$ contributed to a decrease in grain yield with the same semi-steam tillage system by $0.48 \mathrm{t} / \mathrm{ha}$, or $8.8 \%$. In the variants of the irrigation half-pair, when applying an increased dose of mineral fertilizers, the grain yield was lower compared to the half-steam system by $0.46 \mathrm{t} / \mathrm{ha}$, or $8.4 \%$.
\end{abstract}

Keywords: Meadow-chestnut soil; Doses of fertilizers; Tillage systems; Winter hard wheat; Yield

\section{Introduction}

In increasing the production of grain of better quality, the leading role belongs to durum wheat. Durum wheat grain is distinguished by its high content of protein, gluten, virtuousness, in-kind, fine-stiffness and a large percentage of flour yield $[1,2]$.

The uniqueness of durum wheat lies in the fact that exclusively from its varieties it turns out special coarse-grained flour "grains", which serves as an indispensable raw material for the manufacture of pasta. The strength of pasta made from durum wheat winter flour increases with long-term storage and decreases from soft ones [3].

Variety selection is a determining factor in the intensification of agricultural technologies and at the same time the most costintensive. Only due to the correct selection of the variety can the crop yield be increased by $30-50 \%$. At the stage of selection of the variety, the determining factor is the yield and product quality, as well as the possibility of cultivation in specific soil-climatic conditions, resistance to diseases, pests and weeds, frost and winter hardiness, drought resistance, resistance to lodging and shedding, i.e. adaptability to adverse cultivation conditions [4].
Russia is the world's largest producer of durum wheat. At present, Russia ranks first in the world in the area of durum wheat crops. Of the 16.2 million hectares of durum wheat in the world, Russia accounts for about 1.2 million hectares [5].

In the Republic of Dagestan, durum wheat was cultivated in 1856. A.I. Bazhanov describes hard wheat bred in the Caucasus near the town of Derwent (in the south of Dagestan), under the local name "Sary-Bugda". Durum wheat crops are mainly concentrated in the lowland and foothill parts of Dagestan [6].

The cultivar of winter durum wheat we study, Krupinka, is high-yielding, more adaptive to adverse cultivation conditions as compared with other varieties of winter durum wheat, zoned in the Republic of Dagestan [7].

The studies were carried out in the FSUE of Kirov, Khasavyurt district, on meadow-chestnut heavy loamy soil in 2014-2018.

\section{The purpose of the research}

It was to obtain experimental data for the development of a cost-effective, environmentally friendly resource-saving 
technology of cultivation of a new promising winter durum wheat variety Krupinka based on the determination of effective doses of mineral fertilizers and the timing of their application against the background of various systems for treating meadow RD irrigation.

\section{The technique}

Studies were conducted in 2014-2018. on meadow-chestnut soil of heavy mechanical composition, moderate degree of cultivation in field experiments laid down in the FSUE. Kirov Khasavyurt district on the basis of methodological provisions: Modeling of zonal farming systems of field experiments, Methodology for determining the ecological-economic efficiency of agricultural production, Field Experience Technique. One two-factor field experience was laid:

Experience number 1 . The impact of tillage systems and doses of mineral fertilizers on the yield and grain quality of winter durum wheat variety Krupinka.

The plot area is 112.5 square meters. m. (7.5x15); accounting $100.8 \mathrm{~m}^{2}$ (7.2x14); repetition - 4 times.

In order to study the effect of soil treatment systems on the fertility and productivity of winter wheat of Krupinka variety, the following counts and observations were carried out:

- Soil moisture - by drying in the active layer $(0-60 \mathrm{~cm})$ in layers every $10 \mathrm{~cm}$, before sowing and before harvesting.

- The density of the soil - the conventional method for layers $0-10,10-20 \mathrm{~cm}$.

- Humus - according to Tyurin.

- Hydrolyzed nitrogen according to Tyurin-Kononova.

- The content of nitrate nitrogen - Grandval-Lyazhu.

- Phosphorus - according to Machigin.

- Potassium in a $1 \%$ ammonium carbon extract.

Accounting for the number of weeds and determining their species composition was carried out by a quantitative-weight method on fixed areas of $0.25 \mathrm{~m}^{2}$, before sowing and before harvesting. The yield was determined by the method of continuous combining. Statistical processing of the yield data was carried out by the method of variance analysis using PC.

The variety was sown on three levels of mineral nutrition: a) No fertilizer (control). b) $\mathrm{N}_{90} \mathrm{P}_{50}\left(\mathrm{~N}_{10} \mathrm{P}_{50}\right)$ amorphous for basic processing, $\mathrm{N}_{30}$ ammonium nitrate, in the tillering phase $\mathrm{N}_{30}$ output into the tube, $\mathrm{N}_{20}$ carbamide (in the earing phase). c) $\mathrm{N}_{180} \mathrm{P}_{100}$ $\left(\mathrm{N}_{120} \mathrm{P}_{100}\right)$ for basic processing, $\mathrm{N}_{60}$ - in the tillering stage, $\mathrm{N}_{60}-$ in the outlet phase, $\mathrm{N}_{40}$ - in the heading phase.

\section{We studied two tillage systems}

Tillage in an irrigated semi-pair system, the control, which consisted: a) in conducting water recharge irrigation following the harvesting of the predecessor, using the remaining irrigation network at a rate of $1200 \mathrm{~m}^{3} / \mathrm{ha}$; b) $2-3$ disking by $12-15 \mathrm{~cm}$ as weeds grow, July - August (DT-75M + BDT-3); c) plow plowing at 20$22 \mathrm{~cm}$ at the beginning of the second decade of September (T-150 + PLN-4-35); d) transverse disking with simultaneous harrowing in the second decade of September (DT-75M + BDT-3 + 3BZSS-1).

Semi-steam tillage system: a) stubble stubbing to a depth of $6-8 \mathrm{~cm}$, following the harvesting of the precursor (T-150 + LDG-5); b) plow plowing at $20-22 \mathrm{~cm}$ in the third decade of July (T-150+ PNL-6-35); c) leveling of the soil surface by a small-leveler (MB6), after plowing; d) water recharge irrigation at a rate of 1200 $\mathrm{m}^{3} /$ ha in the third decade of August; e) disking at $12-15 \mathrm{~cm}$ with simultaneous harrowing before sowing (DT-75M + BDT-3 + 3BZSS1).

Studies conducted indicators that the studied prima cultivation had a significant impact on field germination of seeds: $81.8 \%$ and the density of standing plants. According to these indicators, the best results were achieved in the option of applying an increased dose of mineral fertilizers $\left(\mathrm{N}_{180} \mathrm{P}_{100}\right)$, against the background of a semi-pair tillage system, where these figures were, respectively, $81.8 \%$ and 409 plants per $1 \mathrm{~m}^{2}$. In the variants of application of the irrigation semi-pair system, these indicators were lower by $7.8 \%$ and amounted to $75.2 \%$ of field seed germination with 370 plants per $1 \mathrm{~m}^{2}$. Studied doses and timing of application of mineral fertilizers had a significant impact on the yield of winter durum wheat variety Krupinka.

An important indicator of the effectiveness of the use of water in crops sown on the field as precipitation or irrigation is the coefficient of water consumption, which shows the water consumption for the creation of a grain unit [3]. In our research, the semi-steaming treatment system turned out to be the most effective tillage system for winter wheat, where an average of $1252.2 \mathrm{~m}^{3}$ of water is consumed to produce 1 ton of grain, with $1,511.4 \mathrm{~m}^{3}$ of water per 1 ton of grain per variant of irrigation semi-pair. This is $15.0 \%$ more than in the variant of the semi-steam tillage system (Table 1).

Table 1: The coefficient of water consumption of winter wheat in depending on tillage systems, $2015-2018$.

\begin{tabular}{|c|c|c|c|c|}
\hline Soil Treatment System & Year & Total Water Consumption, $\mathbf{m}^{\mathbf{3}}$ /ha & Grain Yield, t/ha & Water Consumption Ratio \\
\hline \multirow{5}{*}{ Polnevnoe Polar, Control } & 2015 & 5641 & 4.09 & 1379.2 \\
\cline { 2 - 5 } & 2016 & 5960 & 3.86 & 15440 \\
\cline { 2 - 5 } & 2017 & 6386 & 4.24 & 1506.1 \\
\cline { 2 - 5 } & 2018 & 5610 & 3.71 & 1512.2 \\
\cline { 2 - 5 } & Medium & 5899 & 3.97 & 1511.4 \\
\hline
\end{tabular}




\begin{tabular}{|c|c|c|c|c|}
\hline \multirow{5}{*}{ Semi-Pary } & 2015 & 5155 & 4.39 & 1174.3 \\
\cline { 2 - 5 } & 2016 & 5530 & 4.28 & 1292.0 \\
\cline { 2 - 5 } & 2017 & 6082 & 4.62 & 1316.4 \\
\cline { 2 - 5 } & 2018 & 5052 & 4.12 & 1226.2 \\
\cline { 2 - 5 } & Medium & 5455 & 4.35 & 1252.2 \\
\hline
\end{tabular}

Studies $[5,6]$ found that the most favorable conditions for the germination of seeds of winter wheat and the emergence of full seedlings are formed when the moisture content in the soil is within $20-23 \%$ by weight of absolutely dry soil. When soil moisture is $16-$ $17 \%$, seedlings appear at optimum times, while a further decrease in soil moisture content leads to a decrease in field germination, late seedlings and spoilage of part of the seeds, which is the main cause of low yields of winter crops in such conditions.

Studies have shown that on average for 2014-2017, before sowing winter wheat, soil density in the 0-10 layer on the irrigated semi-pair variant was $1.08 \mathrm{~g} / \mathrm{cm}^{3}$, and on the semi-pair treatment variant it was $1.10 \mathrm{~g} / \mathrm{cm}^{3}$. In the soil layer of $10-20 \mathrm{~cm}$, the density of the soil on the irrigated semi-pair variant was $1.10 \mathrm{~g} / \mathrm{cm}^{3}$, and during the semi-steaming treatment it was slightly higher and amounted to $1.12 \mathrm{~g} / \mathrm{cm}^{3}$. By harvesting, the density of the soil increased to $1.28-1.30 \mathrm{~g} / \mathrm{cm}^{3}$. It must be assumed that this indicator is the "equilibrium" density of the arable layer of the heavy loamy soil of the lowland zone of Dagestan.
It should be noted that the tillage in both systems after water recharge irrigation was carried out with the physical ripeness of the soil and the index of soil crumbling is $84-85 \%$, i.e. processing quality is characterized as "good".

Studied doses of mineral fertilizers and tillage systems had a significant impact on the photosynthetic activity of winter durum crops. So, on average for 2014-2018. the best indicators of leaf area - 46.3 thousand $\mathrm{m}^{2} / \mathrm{ha}$, the photosynthetic potential of crops -2.53 million $\mathrm{m}^{2} /$ ha. days and the net productivity of photosynthesis $5.2 \mathrm{~g} / \mathrm{m}^{2}$. day achieved in the option of making an increased dose of mineral fertilizers $\left(\mathrm{N}_{180} \mathrm{P}_{100}\right)$ against the background of a semisteam tillage system.

The use of the irrigated semi-pair system resulted in a decrease in the leaf surface area in comparison with the semi-pair processing system in the optimal variant by $-11.0 \%$, the photosynthetic potential of the crops by $-10.7 \%$ and the net productivity of photosynthesis by $21.2 \%$ (Table 2 ).

Table 2: Photosynthesis of sunflower husks in different types of crops and different soil and soil treatments, average for 2014-2018.

\begin{tabular}{|c|c|c|c|c|}
\hline Soil Treatment System & $\begin{array}{l}\text { Dose of Mineral } \\
\text { Fertilizers }\end{array}$ & $\begin{array}{l}\text { Leaf Surface Area, } \\
\text { thousand } \mathrm{m}^{2} / \mathrm{ha}\end{array}$ & $\begin{array}{l}\text { Photosynthetic Potential of Crops, } \\
\text { thous. } \mathrm{m}^{2} / \text { ha. days }\end{array}$ & $\begin{array}{l}\text { Net Productivity of Photo- } \\
\text { synthesis, } \mathrm{g} / \mathrm{m}^{2} \text {. day }\end{array}$ \\
\hline \multirow{3}{*}{ Polnevnoe Polar, Control } & $\begin{array}{l}\text { Without A Comfort, } \\
\text { (Controls) }\end{array}$ & 30.3 & 1.65 & 2.9 \\
\hline & $\mathrm{N}_{50} \mathrm{P}_{90}$ & 37.6 & 2.02 & 3.7 \\
\hline & $\mathrm{N}_{100} \mathrm{P}_{180}$ & 41.2 & 2.26 & 4.1 \\
\hline \multirow{3}{*}{ Semi-Pary } & $\begin{array}{l}\text { Without A Comfort, } \\
\text { (Controls) }\end{array}$ & 32.8 & 1.79 & 3.1 \\
\hline & $\mathrm{N}_{50} \mathrm{P}_{90}$ & 39.8 & 2.11 & 5.0 \\
\hline & $\mathrm{N}_{100} \mathrm{P}_{180}$ & 46.3 & 2.53 & 5.2 \\
\hline
\end{tabular}

It has been established that the favorable conditions for the growth of seed potatoes and the emergence of pollutant byproducts in soils have been reached in the soil in the range of 20 $23 \%$ of total dry matter. With moistures in the soil, $16-17 \%$, in the best possible time, how to improve the moisture content of the soil in the soil, the soil in the soil and the parts of the seed, which are the main causes of the crop.

In the meantime, for the years 2014-2017, surveys showed that the soil in the 0-10 layer of the semi-sparking plant was $1.08 \mathrm{~g} /$ $\mathrm{cm}^{3}$, and in the semi-parboiled treatments it was $1.10 \mathrm{~g} / \mathrm{cm}^{3}$. In a layer of soil of $10-20 \mathrm{~cm}$, the soil of the variants of a polyvalent semistarch was $1.10 \mathrm{~g} / \mathrm{cm}^{3}$, and in the case of a semi-parboiled process, it was not sufficient to store $1.12 \mathrm{~g} / \mathrm{cm}^{3}$. The uterus has a surface area of up to $1.28-1.30 \mathrm{~g} / \mathrm{cm}^{3}$. Surprisingly, this indicator is the "equilibrium" surface of the passionate weir layer weighed in the flat area of Dagestan.

Afterwards, the treatment of the soil at the inlet system and then the moisture boiler, in the case of physical spraying, has been observed and the soil content of the soil is $84-85 \%$. quality treatments characterize how "horse".

Exhausted mineral resources and soil treatment systems have a major impact on the photosynthetic of the soil and the soil. Take, in the middle of 2014-2018, best leaf surface area - 46.3 thousand. $\mathrm{m}^{2} /$ ha, photosynthetic potential sowing -2.53 million $\mathrm{m}^{2} /$ ha. today and clean products photosynthesis $-5.2 \mathrm{~g} / \mathrm{m}^{2} .\left(\mathrm{N}_{180} \mathrm{P}_{100}\right)$ on the background of the semi-conductor systems of the soil.

In the optimal version of $-11.0 \%$, the photosynthetic potential of the crop $-10.7 \%$ and the pure photosynthesis productivity 
at $21.2 \%$ (Table 2), the system was used for polymorphing of polysaccharides compared to semi-pollen system treatments.

\section{Result}

As a result of the overthrow of the agricultural crops, a huge amount of sorghum has been postponed with the oyster barrier on the plains. Satisfaction needs to grow plants with the same crops, pronounced intense rhinoceros spp and serotine. Remove dripping seeds from sowing. Partial is the difficulty of the crop plants and the ingestion of the large amounts of nutrients, much needed on the crop plants, the disease for the last $10-15$ years of economic transformation has been made in organic farming and mining. The system is designed to handle soil and mineral deposits and has a significant impact on the soil and the soil in the soil (Table 3).

Table 3: Growth of crops in dependence on the mineral content and the soil treatment systems, average for 2015-2018 years. (before harvest).

\begin{tabular}{|c|c|c|c|c|}
\hline \multirow{2}{*}{ Soil Treatment System } & \multirow{2}{*}{ Dose of Mineral Fertilizers } & Number of Weeds, Pieces/sq.m & \multicolumn{2}{|c|}{ Mass of Weeds, gr. } \\
\cline { 2 - 5 } & No Fertilizer Control & 22 & 30.8 & 14.2 \\
\hline \multirow{3}{*}{ Polymnoi Half-Par, } & $\mathrm{N}_{90} \mathrm{P}_{50}$ & 23 & 32.2 & 14.8 \\
\cline { 2 - 5 } & $\mathrm{N}_{180} \mathrm{P}_{100}$ & 21 & 29.4 & 13.5 \\
\cline { 2 - 5 } & No Fertilizer Control & 16 & 21.4 & 10.2 \\
\cline { 2 - 5 } & $\mathrm{N}_{90} \mathrm{P}_{50}$ & 17 & 20.0 & 10.8 \\
\cline { 2 - 5 } & $\mathrm{N}_{180} \mathrm{P}_{100}$ & 17 & 10.8 \\
\hline
\end{tabular}

Many types of weeds have a great competitive ability, so their timely removal from crops is absolutely necessary. They impede harvesting, reduce the productivity of harvesting aggregates, impair the quality of the products $[7,8]$.

On average over the years of research, the smallest number of weeds - $17 \mathrm{pcs} . / \mathrm{m}^{2}$ contained in a semi-steam tillage system. The use of the irrigation semi-pair system resulted in an increase in weed infestation by an average of $22.7 \%$.
In crops, one-year dicotyledonous weeds were the most common - white martens, field mustard, field currant, shepherd's purse, wild radish, schpritzer, rapeseed, chamomile, odorless, pickle, etc.

On average for 2015-2018, the maximum yield of winter durum wheat $-5.45 \mathrm{t} / \mathrm{ha}$ was achieved with the introduction of an increased dose of mineral fertilizers - $\left(\mathrm{N}_{180} \mathrm{P}_{100}\right)$ against the background of a semi-steam tillage system, which is $0.46 \mathrm{t} / \mathrm{ha}$, or $8.4 \%$ more than in the variant of irrigation semi-pair.

Table 4: Yield of winter durum wheat of the Krupinka variety depending on the doses and timing of the application of mineral fertilizers against the background of various soil treatment systems, 2015-2018, t/ha.

\begin{tabular}{|c|c|c|c|c|c|c|}
\hline \multirow{2}{*}{ Soil Treatment System } & \multirow{2}{*}{ Fertilizer Dose } & \multicolumn{5}{|c|}{ Years: } \\
\hline & & 2015 & 2016 & 2017 & 2018 & The Average \\
\hline \multirow{3}{*}{ Polymnoi Polar, (Control) } & Without Fertilizer & 3.04 & 2.53 & 2.86 & 2.24 & 2.67 \\
\hline & $\mathrm{N}_{90} \mathrm{P}_{50}$ & 4.71 & 4.60 & 4.82 & 4.42 & 4.64 \\
\hline & $\mathrm{N}_{180} \mathrm{P}_{100}$ & 5.02 & 4.94 & 5.24 & 4.78 & 4.99 \\
\hline \multirow{3}{*}{ Semi-Pary } & Without Fertilizer & 3.22 & 2.87 & 3.20 & 2.64 & 3.01 \\
\hline & $\mathrm{N}_{90} \mathrm{P}_{50}$ & 4.88 & 4.93 & 5.28 & 4.78 & 4.97 \\
\hline & $\mathrm{N}_{180} \mathrm{P}_{100}$ & 5.36 & 5.53 & 5.68 & 5.23 & 5.45 \\
\hline $\mathrm{HCP}_{05}$ & - & 0.28 & 0.26 & 0.27 & 0.26 & - \\
\hline
\end{tabular}

The greatest increase in grain yield - $2.44 \mathrm{t} / \mathrm{ha}$ compared with the control (without fertilizers) was achieved when a higher dose of mineral fertilizers was applied $\left(\mathrm{N}_{180} \mathrm{P}_{100}\right)$ against the background of a semi-steam tillage system (Table 4).
The introduction of half the dose of mineral fertilizers $-\mathrm{N}_{90} \mathrm{P}_{50}$ contributed to a decrease in grain yield as compared with the option of increasing the dose with irrigated semi-pair by $7.0 \%$ and with semi-steam tillage system by $8.8 \%$.

Table 5: Structure of grain yield of winter durum wheat, average for 2015-2018.

\begin{tabular}{|c|c|c|c|c|c|c|c|}
\hline $\begin{array}{c}\text { Soil Treatment } \\
\text { System }\end{array}$ & $\begin{array}{l}\text { Dose of Mineral } \\
\text { Fertilizers }\end{array}$ & $\begin{array}{c}\text { Number of } \\
\text { Plants Per } 1 \mathrm{~m}^{2}\end{array}$ & $\begin{array}{l}\text { Total Number of } \\
\text { Stems Per } 1 \mathbf{~ m}^{2}\end{array}$ & $\begin{array}{l}\text { Qty Product. } \\
\text { Stalks on } 1 \text { m² }^{2}\end{array}$ & $\begin{array}{l}\text { Coefficient Prod- } \\
\text { ucts Bushiness }\end{array}$ & $\begin{array}{l}\text { Grain Mass } \\
\text { Per Spike }\end{array}$ & $\begin{array}{l}1000 \text { Grains } \\
\text { Weight }\end{array}$ \\
\hline \multirow{3}{*}{$\begin{array}{l}\text { Polnevnoe Polar, } \\
\text { Control }\end{array}$} & $\begin{array}{l}\text { Without Hitting, } \\
\text { Control }\end{array}$ & 320 & 352 & 344 & 1,10 & 0.81 & 31.6 \\
\hline & $\mathrm{N}_{90} \mathrm{P}_{50}$ & 345 & 388 & 376 & 1,23 & 1.14 & 38.0 \\
\hline & $\mathrm{N}_{180} \mathrm{P}_{100}$ & 369 & 453 & 445 & 1,20 & 1.26 & 42.0 \\
\hline \multirow{3}{*}{ Semi-Pary } & No Stress, Control & 343 & 367 & 354 & 1,23 & 0.90 & 34.6 \\
\hline & $\mathrm{N}_{90} \mathrm{P}_{50}$ & 364 & 502 & 464 & 1,33 & 1.23 & 41.0 \\
\hline & $\mathrm{N}_{180} \mathrm{P}_{100}$ & 390 & 580 & 562 & 1,53 & 1.35 & 45.0 \\
\hline
\end{tabular}


Analysis of the structure of the winter wheat harvest shows that both the number of plants and productive stems per unit area in the variants of the semi-steaming system was greater than the irrigated semi-pair. Thus, on average for 2015-2018, the best indicators in the number of plants per $1 \mathrm{~m}^{2}$ are -390 pcs., Productive stems - 562, productivity coefficient -1.53 , the mass of grain from one ear is $1.35 \mathrm{~g}$ and the mass is 1000 seeds (absolute weight) $-45 \mathrm{~g}$ were achieved in the option of making an increased dose of mineral fertilizers on the background of a semi-steam tillage system. On the irrigated semipair variant per $1 \mathrm{~m}^{2}$, there were 369 plants, productive stems - 445 pcs., Tailoring factor -1.20 , grain weight from one ear $-1.26 \mathrm{~g}$ and mass of 1000 seeds - $42.0 \mathrm{~g}$ (Table 5).

On the half-dose fertilizer application options and on the control variants with both tillage systems, the yield structure indicators were lower.

Table 6: Effect of doses of mineral fertilizers on sowing, physical, technological and other qualities of grain, average for 2015-2018.

\begin{tabular}{|c|c|c|c|}
\hline Indicators & No convenience Control & $\mathbf{N}_{\mathbf{g}_{\mathbf{0}}} \mathbf{P}_{\mathbf{5 0}}$ & $\mathbf{N}_{\mathbf{1 8 0}} \mathbf{P}_{\mathbf{1 0 0}}$ \\
\hline Germination energy (\%) & 84 & 94 & 95 \\
\hline Germination (\%) & 90 & 810 & 98 \\
\hline Nature of grain (g/l) & 799 & 99 & 912 \\
\hline Virtuousness (\%) & 97 & 15.4 & 15.8 \\
\hline Protein content (\%) & 14.6 & 39.2 & 39.4 \\
\hline Gluten content (\%) & 38.4 & 642 & 643 \\
\hline Pasta grain quality (units) & 630 & 68.0 & 68.3 \\
\hline
\end{tabular}

Studies have shown that the best performance in germination energy (95\%), germination (98\%), grain nature ( $812 \mathrm{~g} / \mathrm{l})$, glassiness (99\%), protein content (15.8\%), gluten (39.4\%), macaroni quality and cereal yield were achieved on a variant of a semi-steam tillage system and an increased dose of mineral fertilizers $\left(\mathrm{N}_{180} \mathrm{P}_{100}\right)$ (Table $6)$.

Table 7: The economic efficiency of cultivation of winter durum wheat depending on the doses of mineral fertilizers and tillage systems, the average for 2015-2018 (rub / ha).

\begin{tabular}{|c|c|c|c|c|c|c|c|}
\hline $\begin{array}{c}\text { Soil Treatment } \\
\text { System }\end{array}$ & Fertilizer Dose & Productivity, t/ha & Expenses & $\begin{array}{c}\text { Cost of } \\
\text { Production }\end{array}$ & Net Income & $\begin{array}{l}\text { Cost of } 1 \\
\text { t/RUB. }\end{array}$ & Profitability, \% \\
\hline \multirow{3}{*}{$\begin{array}{c}\text { Polnevnoe Polar, } \\
\text { Control }\end{array}$} & $\begin{array}{l}\text { Without Comfort, } \\
\text { Control }\end{array}$ & 2.67 & 9600 & 18690 & 9090 & 3595.4 & 94.7 \\
\hline & $\mathrm{N}_{50} \mathrm{P}_{90}$ & 4.26 & 11496 & 29820 & 18324 & 2698.6 & 159.4 \\
\hline & $\mathrm{N}_{100} \mathrm{P}_{180}$ & 4.99 & 15640 & 34930 & 19290 & 3134.3 & 123.3 \\
\hline \multirow{3}{*}{ Semi-Pary } & $\begin{array}{l}\text { Without Comfort, } \\
\text { Control }\end{array}$ & 3.01 & 9600 & 21070 & 11470 & 3189.4 & 119.5 \\
\hline & $\mathrm{N}_{50} \mathrm{P}_{90}$ & 4.62 & 11496 & 32340 & 20844 & 2488.3 & 181.3 \\
\hline & $\mathrm{N}_{100} \mathrm{P}_{180}$ & 5.45 & 15940 & 38150 & 22210 & 2924.8 & 139.3 \\
\hline
\end{tabular}

The grain quality indicators close to the increased dose of mineral fertilizers were also obtained when a half dose of mineral fertilizers was applied. On the control variant (without fertilizers), these indicators were lower (Table 7).

The best indicators of economic efficiency were achieved in the variant of the semi-steam tillage system and the introduction of half the dose of mineral fertilizers - $\mathrm{N}_{90} \mathrm{P}_{50}$, where on average for 2015-2018, the cost of 1 ton of grain was 2488.3 rubles. while the profitability of production is $181.3 \%$. In the irrigated semi-pair variant, these indicators were lower and amounted to 2,698.6. rub. with a profitability of production of $159.4 \%$.

In the option of applying an increased dose of mineral fertilizers, the prime cost of 1 ton of grain for a semi-steam tillage system was 2924.8 rubles. with a profitability of production of $139.3 \%$, respectively, of 436.5 rubles. higher and $42 \%$ lower than with a half dose of mineral fertilizers (Table 7).
Dagestan Optimal Dose Minerals approved after the $\mathrm{N}_{90} \mathrm{P}_{50^{\prime}}$ which received the indicators of economic and energy effectivities. The introduction of the $\mathrm{N}_{180} \mathrm{P}_{100}$ has been proven to be the most effective and efficient way of doing business, economically and energy fully.

\section{Conclusion}

1. In the Territorial and Sulawesian sub-provinces, the republics of Dagestan show indicators on the standing plant (408 m. $/ \mathrm{m}^{2}$ ), the squares of the sculptures $-46.3 \mathrm{~m} . \mathrm{m}^{2} / \mathrm{ha}$, photosynthetic potential sowing -2.53 million $\mathrm{m}^{2} / \mathrm{ha}$. today and clean products photosynthesis $-5.2 \mathrm{~g} / \mathrm{m}^{2} \cdot\left(\mathrm{n}_{180} \mathrm{p}_{100}\right)$ on the background of the semi-conductor system processing the soil.

2. Maximum yield $-5.45 \mathrm{t} / \mathrm{ha}$, in the middle of $2015-2018$, reached in the variants of the imported landfill mineral deposits $\left(\mathrm{N}_{180} \mathrm{P}_{100}\right)$ on the basis of the semi-finished system of soil 
treatment, at $0.46 \mathrm{t} /$ ha more than in the variation of polyvalent semi-pars.

3. The smallest self-sufficiency per unit of output is $2,488.3$ rubles./T of grain at the level of profitability 181,3\% removed in the variants imported half-finished mineral deposits $\left(\mathrm{N}_{90} \mathrm{P}_{50}\right)$ to the foaming semi-finished processing soil. The introduction of the $\mathrm{N}_{180} \mathrm{P}_{100}$ has resulted in a higher profitability of 1 ton per 436.5 pounds, and a $42 \%$ increase in profitability.

\section{Acknowledgement}

None.

\section{Conflict of Interest}

No conflict of interest.

\section{References}

1. Alabushev AV, Gureeva AV (2011) Seed production of grain crops in Russia. Agriculture 6: 6-7.
2. Bespalova LA, Kudryashov IN, Barshadskaya SI (2011) Efficiency of a new winter wheat variety, soft Thunder and its agroecological address. Farming 4: 12-13.

3. Fedotov VL, Kozlobaev VV, Tsykalov AN (2002) Biological reserves increase the production of durum wheat grain in the Central Black Earth Region. Materials of International Internet Conference. Stavropol, p. 6667.

4. Pasko Starodubtsev VN, Stepanova LP, Korenkova Ye (2011) A Varietal variability, productive adaptive potential and quality of winter wheat varieties. Farming 6: 22-23.

5. Chekmarev PA (2011) Development strategy of breeding and seed production in Russia. Agriculture, 6: 3-4.

6. Magomedov NN (2012) Winter Durum Wheat Productivity on MeadowChestnut Soils of the Terek-Sulak Province of Dagestan. Problems development of the agro-industrial complex of the region 1(9): 44-48.

7. Pasko SV (2008) The effectiveness of varieties of winter durum wheat when fertilizing. Agriculture 7: 41-43.

8. Paramonov AV, Medvedev VI (2015) The influence of fertilizer systems, predecessors on the yield and protein content in the grain of winter wheat in the conditions of the Azov zone of the Rostov region. Scientific support of the AIC at the present stage. - p. Dawn of the Rostov region, pp. 128-132. 